\title{
Numerical and experimental analysis of a tube-and-fin cross- flow heat exchanger with a controlled non-uniform inflow of gas
}

\author{
Tomasz Bury $^{1 *}$, and Małgorzata Hanuszkiewicz-Drapała ${ }^{1}$ \\ ${ }^{1}$ Silesian University of Technology, Department of Thermal Technology, 44-100 Gliwice, Konarskiego 22, Poland
}

\begin{abstract}
The paper presents results of numerical and experimental analyses of a fin-and-tube air-water heat exchanger. The analysed device is a one-row heat exchanger with finned elliptical tubes. The aim of the analyses is to investigate the impact of a controlled non-uniform inflow of air on the heat exchanger performance. The heat exchanger was modelled numerically using the ANSYS Fluent program. The developed model was applied to simulate the heat exchanger operation in the conditions of the uniform inflow of air. Cases of an uncontrolled non-uniform inflow of gas were investigated experimentally, using a purpose-designed test station. On the experimental test station the effect of a controlled non-uniform air inflow was also achieved by placing appropriately shaped inserts in the air inlet duct, directing the air partially to the region of the water inlet header. By controlling the gas inflow, it was possible to significantly enhance the heat exchanger performance. The results of the multivariate numerical analyses conducted for the adopted parameters of the mediums (air and water volumetric flow rates and water temperature) show that the heat exchanger performance can be improved by up to almost $5 \%$ compared to a variant with a natural non-uniform air inflow taking place in the exchanger under consideration.
\end{abstract}

\section{Introduction}

Heat exchangers functioning as devices transferring heat between two or more fluids are the main elements of very many industrial systems. The amount of transferred heat and the heat transport conditions are affected by a number of parameters, such as the heat exchanger size, material and design characteristics. The simplest way to improve the heat exchanger performance is to increase its surface. On the other hand, the mass, size and cost limitations do not allow the use of a big-sized heat exchanger to achieve a better heat exchange. This is the reason for which several heat transfer enhancement methods are considered to improve the heat transfer efficiency without increasing the heat transfer area. [13]. Passive methods are of big interest as they do not require any external energy supply. Such methods are based on geometry modifications or turbulating inserts (turbulators) to enhance the heat exchanger performance. It should be noted that the application of any passive method improving the heat exchange efficiency increases the pressure drop on the device. Many researchers point to another problem affecting the heat exchanger operation - the non-uniform flow of mediums through the device [4-6].

The experimental and computational studies on tube-and-fin heat exchangers with a cross flow of mediums realized in the Department of Thermal Technology (previously: Institute of Thermal Technology) of the Silesian University of Technology have shown that the inflow of working fluids to analysed heat exchangers can be non-uniform [7-11]. Although this non-uniformity refers to both mediums (air and water), the experimental testing is limited to gas flowing through the space between finned tubes. Figure 1 presents a sample distribution of the air inlet velocity for a car radiator (marked as HE-1) tested on the experimental station.

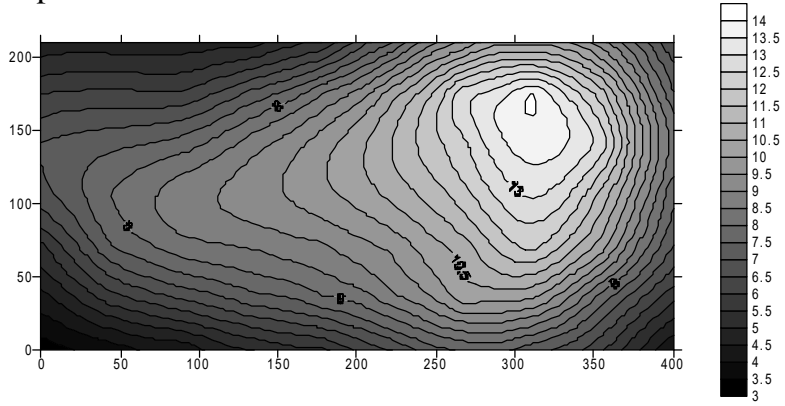

Fig. 1. Sample air inlet velocity distribution $(\mathrm{m} / \mathrm{s})$ for the HE1 heat exchanger

Summarizing these investigations [7-11], it may be stated that the flow non-uniformity can substantially deteriorate the performance of the considered devices. The reduction in the total transferred heat, in comparison to a heat exchanger with a uniform inflow of the mediums, reached nearly $20 \%$ for some working modes [7-9,12].

Due to various technical limitations, it may be impossible to make the flow of fluids uniform. The authors of [13] assumed that it was possible to increase the performance of the HE-1 heat exchanger operating in the conditions of a non-uniform flow of the mediums by applying a passive method. However, the application

\footnotetext{
* Corresponding author: tomasz.bury@.polsl.pl
} 
of an air turbulator in the form of a spirally wrapped and axially extruded metal sheet (see Fig. 2) produced a negative effect.

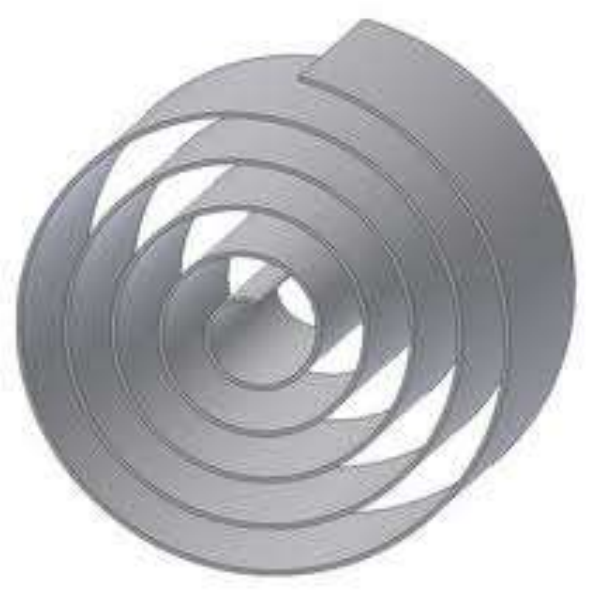

Fig. 2. Air turbulator used to improve the HE-1 heat exchanger operation in the conditions of a non-uniform flow of mediums [13]

This paper presents the results of numerical and experimental analyses of a fin-and-tube air-water heat exchanger as presented in Fig. 3 (HE-2). The HE-2 core is a one-row structure containing ten elliptic tubes with 175 plate fins on each tube. It is assumed that the inflow of gas will be non-uniform, but controlled, at least to some degree. The general idea is to force more air to flow near the hot water inlet header to improve the heat exchanger performance. This technique is herein referred to as the controlled non-uniform inflow of mediums.

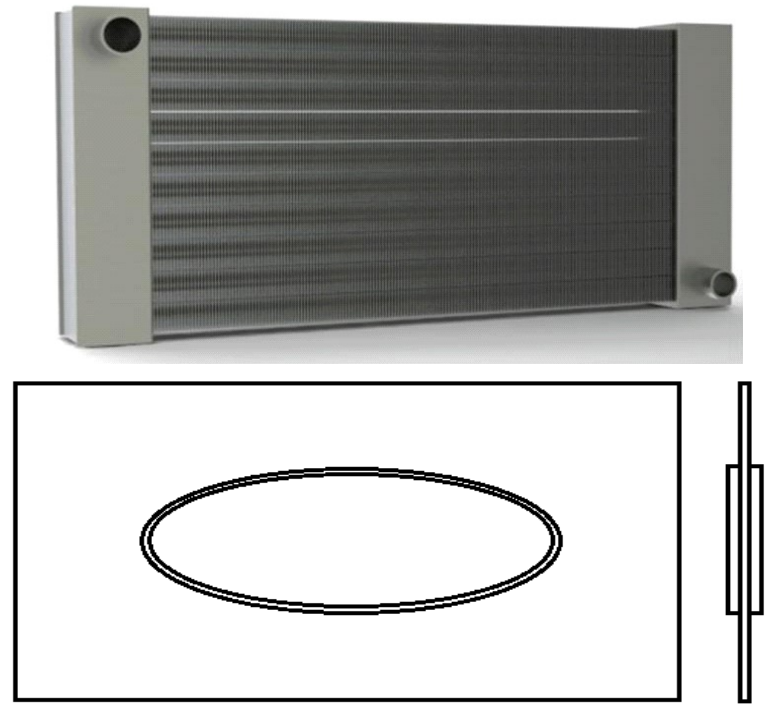

Fig. 3. General view of the HE-2 heat exchanger and a detail of its core

The aim of this paper is to verify the hypothesis that directing more air to the region of higher water temperature will improve the heat exchanger performance.

\section{Tools for the analysis}

\subsection{Numerical model}

The authors applied the CFD model built using the ANSYS Fluent program and presented in [11] and [12]. The numerical model makes it possible to carry out calculations for uniform and non-uniform flows of air and water. The basic assumption of the model is that the real heat exchanger is divided into recurrent segments, as presented in Fig. 4. The division is strictly related to the measurements scheme.

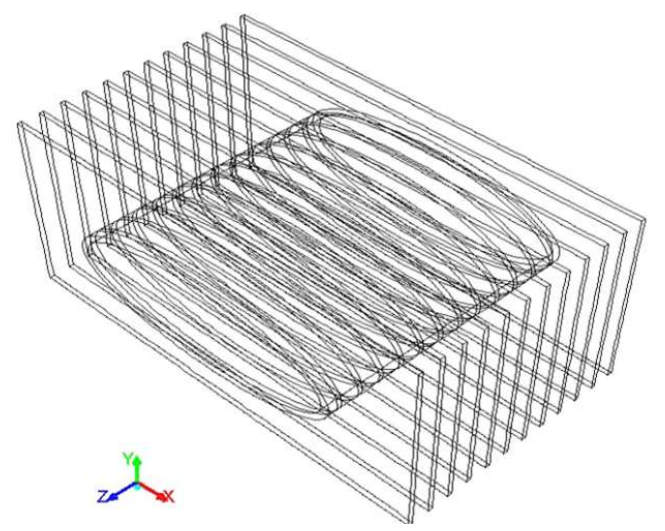

Fig. 4. Geometry of the recurrent core segment of the HE-2 heat exchanger

The model geometry includes 12 fins with an adjacent tube section, and the air volume neighbouring the core section, as presented in Fig. 5.

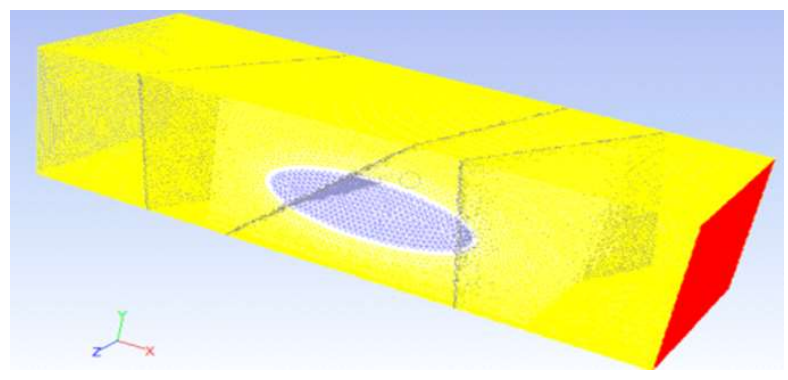

Fig. 5. Geometry of the recurrent segment (core + air volume) of the HE-2 heat exchanger

The numerical mesh consists of nearly 1 million cells. The boundary conditions set in the model are the inlet and the outlet velocity for the air inflow and outflow modelling, the inlet and the outlet mass flow for the water flow, and symmetry for the remaining boundaries of the computational domain. The most important results are the heat transfer rates for each recurrent segment.

The governing equations include:

- the energy balance,

- the momentum equation,

- the continuity equation,

- the k- $\varepsilon$ turbulence model.

Air is treated as ideal gas. In the case of a nonuniform flow of the mediums, the values of the air velocity as the boundary condition are the results of measurements, while the water-side boundary 
conditions are defined according to the so-called hydraulic model of the heat exchanger [12].

The computational procedure requires running the simulations for subsequent segments. The main result of such sequential calculations is the heat exchanger heat performance.

\subsection{Test stand and method of experimental results analysis}

The measurements were performed on the test stand designed and made in the Department of Thermal Engineering of the Silesian University of Technology. It consists of the air supply module and the hot water supply module (cf. Figs. 6 and 7).

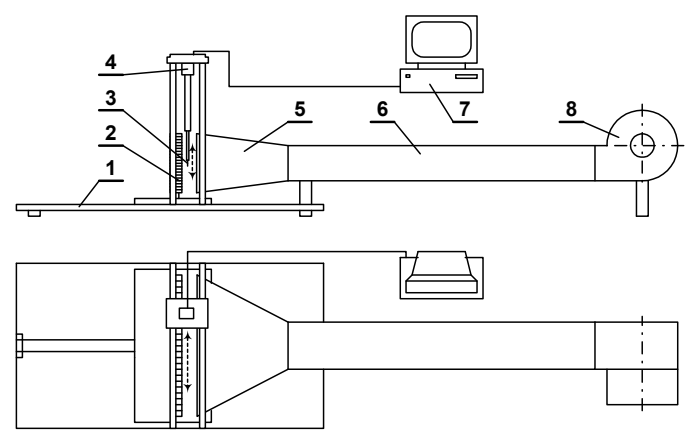

Fig. 6. Air supply module (1 - support plate, 2 - heat exchanger, 3 - thermo-anemometric sensor, 4 - measuring probe, 5 - diffuser, 6 - channel, 7 - control computer, 8 - fan)

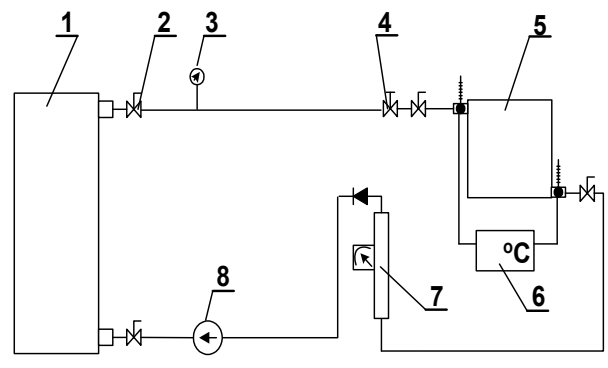

Fig. 7. Hot water supply module $(1-$ electric heater, 2 - cutoff valve, 3 - manometer, 4 - control valve, 5 - heat exchanger, 6 - temperature measuring system, 7 - flow meter, 8 - pump)

\begin{tabular}{|l|l|l|l|l|l|l|l|}
\hline 0 & 0 & 0 & 0 & 0 & 0 & 0 & 0 \\
\hline 0 & 0 & 0 & 0 & 0 & 0 & 0 & 0 \\
\hline 0 & 0 & 0 & 0 & 0 & 0 & 0 & 0 \\
\hline 0 & 0 & 0 & 0 & 0 & 0 & 0 & 0 \\
\hline 0 & 0 & 0 & 0 & 0 & 0 & 0 & 0 \\
\hline 0 & 0 & 0 & 0 & 0 & 0 & 0 & 0 \\
\hline 0 & 0 & 0 & 0 & 0 & 0 & 0 & 0 \\
\hline
\end{tabular}

Fig. 8. Diagram of the inlet/outlet plane division into measuring fields and trajectory of the thermo-anemometric probe shifting

The stand makes it possible to measure the air temperature and velocity distributions at the inlet and outlet cross-sections of the heat exchanger, the air and water volumetric flow rates and water temperatures at the inlet and outlet of the tubes. The main element of the stand is the single wire thermo-anemometric sensor of the V1T type. It measures temperature and velocity of gas in flows with a defined direction in each measuring field - see Fig. 8. The water temperature measuring system is based on K-type thermocouples.

Three independent parameters have to be set for the experiment: the air flow rate, the water flow rate and the water inflow temperature.

The heat exchanger capacity can be determined using energy balance equations, computed as the increase in air enthalpy or the decrease in water enthalpy.

\section{Results and discussion}

\subsection{Experimental results - reference measurements}

Reference measurements were performed for the heat exchanger under consideration in non-uniform flow conditions, without any action aimed at improving its performance. The experiments being the subject of the analysis presented herein were realized at a varying water flow rate, for three different water temperature values, and for two air flow rates: minimum and maximum. Fig. 9 presents the air inlet velocity distribution for the maximum air flow rate, and Table 1 gathers the other measurement and analysis results. The results for the minimum air flow rate are presented in Fig. 10 and Table 2.

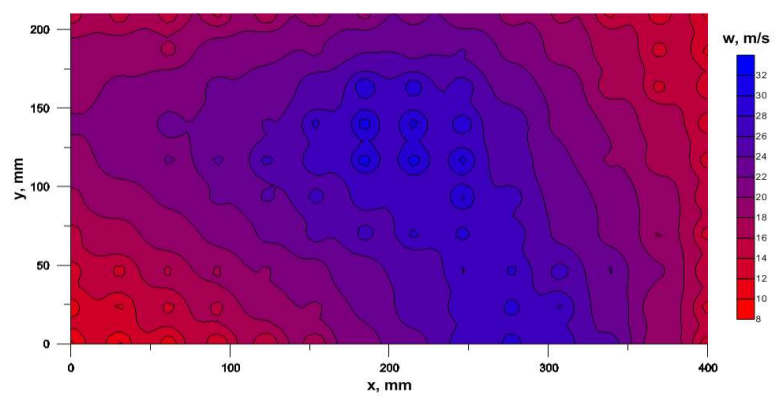

Fig. 9. Air inlet velocity distribution for the HE-2 at the highest air flow rate

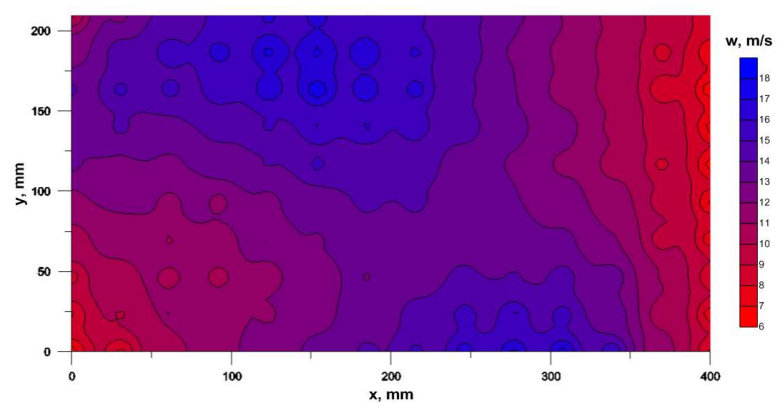

Fig. 10. Air inlet velocity distribution for the HE-2 at the lowest air flow rate

It may be seen in Figs. 9 and 10 that the air inflow to the considered heat exchanger is really non-uniform. The water inlet temperature was set to $50^{\circ} \mathrm{C}, 70^{\circ} \mathrm{C}$ and $90^{\circ} \mathrm{C}$, respectively. The real values of this parameter are 
shown in Tables 1 and 2. As it can be seen, the total heat transfer rate ranges from $4.31 \mathrm{~kW}$ to $15.78 \mathrm{~kW}$, while the inflow of air and water is non-uniform and uncontrolled.

Table 1. Reference measurement results at the maximum air flow rate $\left(6100 \mathrm{~m}^{3} / \mathrm{h}\right)$

\begin{tabular}{|c|c|c|c|}
\hline Meas. ID & HE2-01 & HE2-02 & HE2-03 \\
\hline $\mathrm{V}_{\mathrm{w}}, \mathrm{dm}^{3} / \mathrm{min}$ & 16.9 & 22.3 & 26.5 \\
\hline $\mathrm{t}_{\mathrm{w}, \mathrm{in}}{ }^{\circ} \mathrm{C}$ & 49.3 & 50.5 & 50.3 \\
\hline $\mathrm{t}_{\mathrm{w}, \text { out }}{ }^{\circ} \mathrm{C}$ & 45.1 & 46.5 & 47.1 \\
\hline $\mathbf{Q}, \mathbf{k W}$ & 4.95 & 6.22 & 5.92 \\
\hline Meas. ID & HE2-04 & HE2-05 & HE2-06 \\
\hline $\mathrm{V}_{\mathrm{w}}, \mathrm{dm}^{3} / \mathrm{min}$ & 16.9 & 22.5 & 26.6 \\
\hline $\mathrm{t}_{\mathrm{w}, \mathrm{in}}{ }^{\circ} \mathrm{C}$ & 68.9 & 69.7 & 70.7 \\
\hline $\mathrm{t}_{\mathrm{w}, \text { out }}{ }^{\circ} \mathrm{C}$ & 60.8 & 62.7 & 64.2 \\
\hline $\mathrm{Q}, \mathbf{k W}$ & 9.55 & 10.99 & 12.07 \\
\hline Meas. ID & HE2-07 & HE2-08 & HE2-09 \\
\hline $\mathrm{V}_{\mathrm{w}}, \mathrm{dm}^{3} / \mathrm{min}$ & 16.1 & 22.1 & 26.0 \\
\hline $\mathrm{t}_{\mathrm{w}, \mathrm{in}}{ }^{\circ} \mathrm{C}$ & 87.4 & 88.3 & 88.1 \\
\hline $\mathrm{t}_{\mathrm{w}, \text { out }}{ }^{\circ} \mathrm{C}$ & 74.4 & 78.3 & 79.4 \\
\hline $\mathrm{Q}, \mathrm{kW}$ & 14.61 & 15.42 & 15.78 \\
\hline
\end{tabular}

Table 2. Reference measurement results at the minimum air flow rate $\left(3750 \mathrm{~m}^{3} / \mathrm{h}\right)$

\begin{tabular}{|c|c|c|c|}
\hline Meas. ID & HE2-10 & HE2-11 & HE2-12 \\
\hline $\mathrm{V}_{\mathrm{w}}, \mathrm{dm}^{3} / \mathrm{min}$ & 16.7 & 22.3 & 26.5 \\
\hline $\mathrm{t}_{\mathrm{w}, \text { in }}{ }^{\circ} \mathrm{C}$ & 49.6 & 49.7 & 51.1 \\
\hline $\mathrm{t}_{\mathrm{w}, \text { out }}{ }^{\circ} \mathrm{C}$ & 45.9 & 46.6 & 48.2 \\
\hline $\mathrm{Q}, \mathbf{k W}$ & 4.31 & 4.82 & 5.36 \\
\hline Meas. ID & HE2-13 & HE2-14 & HE2-15 \\
\hline $\mathrm{V}_{\mathrm{w}}, \mathrm{dm}^{3} / \mathrm{min}$ & 16.7 & 22.3 & 26.5 \\
\hline $\mathrm{t}_{\mathrm{w}, \text { in }}{ }^{\circ} \mathrm{C}$ & 70.2 & 70.6 & 70.7 \\
\hline$t_{w, \text { out }}{ }^{\circ} \mathrm{C}$ & 61.8 & 65.3 & 67.3 \\
\hline $\mathrm{Q}, \mathrm{kW}$ & 9.79 & 8.25 & 6.29 \\
\hline Meas. ID & HE2-16 & HE2-17 & HE2-18 \\
\hline $\mathrm{V}_{\mathrm{w}}, \mathrm{dm}^{3} / \mathrm{min}$ & 16.2 & 21.8 & 26.2 \\
\hline $\mathrm{t}_{\mathrm{w}, \text { in }}{ }^{\circ} \mathrm{C}$ & 88.9 & 88.4 & 89.8 \\
\hline$t_{\mathrm{w}, \text { out }}{ }^{\circ} \mathrm{C}$ & 76.9 & 80.5 & 82.4 \\
\hline $\mathrm{Q}, \mathbf{k W}$ & 13.57 & 12.02 & 13.53 \\
\hline
\end{tabular}

\subsection{Numerical simulations - uniform flow}

Technical limitations make it impossible to obtain a uniform inflow of air and water to the heat exchanger on the test stand. For this reason numerical simulations were used to determine the heat exchanger performance in such conditions. All the measurements reported in the previous section were simulated by using the numerical model described in section 2.1. However, in this case the total air and water flow rates were split equally over the air inlet and tubes, respectively. Tables 3 and 4 present the numerical results, as well as the comparison with the previously reported experimental results as the relative difference between the measured and the computed values of the parameter ( $\delta$ in the tables).
Table 3. Results of numerical simulations at the maximum air flow rate $\left(6100 \mathrm{~m}^{3} / \mathrm{h}\right)$ for the uniform flow of mediums

\begin{tabular}{|c|c|c|c|}
\hline Meas. ID & HE2-01 & HE2-02 & HE2-03 \\
\hline $\mathrm{V}_{\mathrm{w}}, \mathrm{dm}^{3} / \mathrm{min}$ & 16.9 & 22.3 & 26.5 \\
\hline $\mathrm{Q}_{\mathrm{NU}}, \mathrm{kW}$ & 4.95 & 6.22 & 5.92 \\
\hline $\mathrm{Q}_{\mathrm{U}}, \mathrm{kW}$ & 5.54 & 7.10 & 6.92 \\
\hline$\delta, \mathbf{\%}$ & $\mathbf{- 1 0 . 6}$ & $\mathbf{- 1 2 . 4}$ & $\mathbf{- 1 4 . 5}$ \\
\hline Meas. ID & $\mathbf{H E 2 - 0 4}$ & $\mathbf{H E 2 - 0 5}$ & HE2-06 \\
\hline $\mathrm{V}_{\mathrm{w}}, \mathrm{dm}^{3} / \mathrm{min}$ & 16.9 & 22.5 & 26.6 \\
\hline $\mathrm{Q}_{\mathrm{NU}}, \mathrm{kW}$ & 9.55 & 10.99 & 12.07 \\
\hline $\mathrm{Q}_{\mathrm{U}}, \mathrm{kW}$ & 10.79 & 12.82 & 14.39 \\
\hline$\delta, \mathbf{\%}$ & $\mathbf{- 1 1 . 5}$ & $\mathbf{- 1 4 . 3}$ & $\mathbf{- 1 6 . 1}$ \\
\hline $\mathrm{Meas.} \mathrm{ID}_{\mathrm{w}}$ & $\mathbf{H E 2 - 0 7}$ & $\mathbf{H E 2 - 0 8}$ & $\mathbf{H E 2 - 0 9}$ \\
\hline $\mathrm{V}_{\mathrm{w}}, \mathrm{dm}{ }^{3} / \mathrm{min}$ & 16.1 & 22.1 & 26.0 \\
\hline $\mathrm{Q}_{\mathrm{NU}}, \mathrm{kW}$ & 14.61 & 15.42 & 15.78 \\
\hline $\mathrm{Q}_{\mathrm{U}}, \mathrm{kW}$ & 16.81 & 18.34 & 19.41 \\
\hline$\delta, \%$ & $\mathbf{- 1 3 . 1}$ & $\mathbf{- 1 5 . 9}$ & $\mathbf{- 1 8 . 7}$ \\
\hline
\end{tabular}

Table 4. Results of numerical simulations at the minimum air flow rate $\left(3750 \mathrm{~m}^{3} / \mathrm{h}\right)$ for the uniform flow of mediums

\begin{tabular}{|c|c|c|c|}
\hline Meas. ID & HE2-10 & HE2-11 & HE2-12 \\
\hline $\mathrm{V}_{\mathrm{w}}, \mathrm{dm}^{3} / \mathrm{min}$ & 16.7 & 22.3 & 26.5 \\
\hline $\mathrm{Q}_{\mathrm{NU}}, \mathrm{kW}$ & 4.31 & 4.82 & 5.36 \\
\hline $\mathrm{Q}_{\mathrm{U}}, \mathrm{kW}$ & 4.52 & 5.12 & 5.88 \\
\hline$\delta, \%$ & $\mathbf{- 4 . 7}$ & $\mathbf{- 5 . 9}$ & $\mathbf{- 8 . 9}$ \\
\hline Meas. ID & $\mathbf{H E 2 - 1 3}$ & $\mathbf{H E 2 - 1 4}$ & HE2-15 \\
\hline $\mathrm{V}_{\mathrm{w}}, \mathrm{dm}^{3} / \mathrm{min}$ & 16.7 & 22.3 & 26.5 \\
\hline $\mathrm{Q}_{\mathrm{NU}}, \mathrm{kW}$ & 9.79 & 8.25 & 6.29 \\
\hline $\mathrm{Q}_{\mathrm{U}}, \mathrm{kW}$ & 10.34 & 8.88 & 6.96 \\
\hline$\delta, \mathbf{\%}$ & $\mathbf{- 5 . 3}$ & $\mathbf{- 7 . 1}$ & $\mathbf{- 9 . 6}$ \\
\hline $\mathrm{Meas.} \mathrm{ID}_{\mathrm{w}}$ & $\mathbf{H E 2 - 1 6}$ & $\mathbf{H E 2 - 1 7}$ & $\mathbf{H E 2 - 1 8}$ \\
\hline $\mathrm{V}_{\mathrm{w}}, \mathrm{dm} / \mathrm{min}$ & 16.2 & 21.8 & 26.2 \\
\hline $\mathrm{Q}_{\mathrm{NU}}, \mathrm{kW}$ & 13.57 & 12.02 & 13.53 \\
\hline $\mathrm{Q}_{\mathrm{U}}, \mathrm{kW}$ & 14.38 & 13.05 & 15.05 \\
\hline$\delta, \%$ & $\mathbf{- 5 . 6}$ & $\mathbf{- 7 . 9}$ & $\mathbf{- 1 0 . 1}$ \\
\hline
\end{tabular}

The results presented in Tables 3 and 4 confirm the previous findings of similar analyses: the non-uniform inflow of fluids to a heat exchanger may significantly deteriorate its efficiency. Analysing the presented values, it can be seen that the deterioration may reach almost $19 \%$.

\subsection{Experimental results - controlled non- uniform flow}

The hypothesis to be verified assumes that the heat exchanger capacity can be improved by forcing more air to flow in the region of a higher temperature difference between water and air. This is the direct neighbourhood 
of the water inlet header. Such shaping of the air inflow was obtained by using metallic inserts mounted before the diffuser, as schematically presented in Fig. 11.

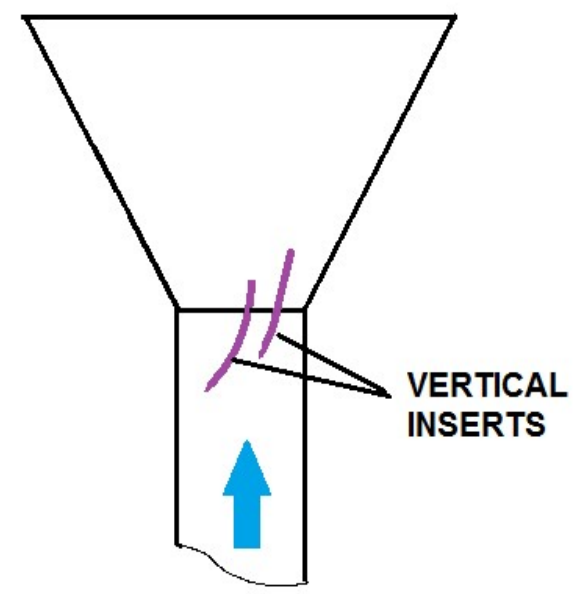

Fig. 11. Diagram of inserts forcing more air to flow closer to the water inlet header

Generally, the aim of mounting these inserts was to obtain the so-called vertical pattern of the air inflow, as shown in Fig. 12.

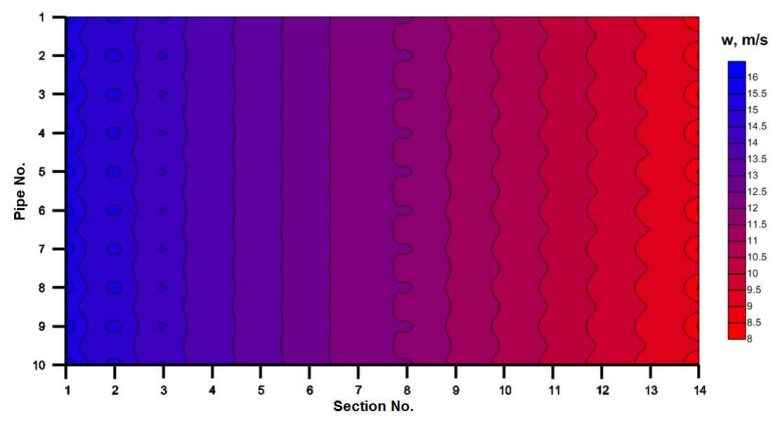

Fig. 12. Vertical pattern of the air inflow - desired state

The whole experimental part was repeated in the described arrangement of the test stand. It should be clearly stated that placing inserts on the air flow path caused an increase in the pressure drop, so it was necessary to regulate the air flow rate to get the same value as during the previous analyses.

The results are presented in Tables 5 and 6 . A simple comparison with the results presented in Tables 1-4 shows that there is some improvement on the uncontrolled non-uniform flow case, and some results are also close to the uniform flow case. The lowest value of the heat output rose from $4.31 \mathrm{~kW}$ (HE1-10 measurement) to $4.58 \mathrm{~kW}$ (HE1-10a), which is an increase of $6.3 \%$. The highest increase in the heat output totals $21.1 \%$ (measurements HE1-09 and HE1-09a).

Table 5. Controlled non-uniform flow measurement results at the maximum air flow rate $(6100 \mathrm{~m} 3 / \mathrm{h})$

\begin{tabular}{|c|c|c|c|}
\hline Meas. ID & HE2-01a & HE2-02a & HE2-03a \\
\hline $\mathrm{V}_{\mathrm{w}, \mathrm{dm}^{3} / \mathrm{min}}$ & 16.8 & 22.4 & 26.6 \\
\hline $\mathrm{t}_{\mathrm{w}, \text { in }}{ }^{\circ} \mathrm{C}$ & 50.3 & 50.2 & 50.3 \\
\hline $\mathrm{t}_{\mathrm{w}, \text { out }}{ }^{\circ} \mathrm{C}$ & 45.3 & 45.6 & 46.5 \\
\hline
\end{tabular}

\begin{tabular}{|c|c|c|c|}
\hline$\overline{Q, k W}$ & 5.61 & 6.98 & 6.78 \\
\hline Meas. ID & HE2-04a & HE2-05a & HE2-06a \\
\hline $\mathrm{V}_{\mathrm{w}}, \mathrm{dm}^{3} / \mathrm{min}$ & 16.9 & 22.5 & 26.6 \\
\hline $\mathrm{t}_{\mathrm{w} \text {,in }}{ }^{\circ} \mathrm{C}$ & 69.5 & 69.7 & 70.2 \\
\hline $\mathrm{t}_{\mathrm{w}, \text { out }}{ }^{\circ} \mathrm{C}$ & 60.0 & 61.4 & 62.4 \\
\hline $\mathbf{Q}, \mathbf{k W}$ & 10.85 & 12.65 & 14.04 \\
\hline Meas. ID & HE2-07a & HE2-08a & HE2-09a \\
\hline $\mathrm{V}_{\mathrm{w}}, \mathrm{dm}^{3} / \mathrm{min}$ & 16.2 & 22.1 & 26.1 \\
\hline $\mathrm{t}_{\mathrm{w} \text {,in }}{ }^{\circ} \mathrm{C}$ & 89.4 & 89.3 & 88.7 \\
\hline$t_{w, \text { out }}{ }^{\circ} \mathrm{C}$ & 73.3 & 77.0 & 77.8 \\
\hline $\mathbf{Q}, \mathrm{kW}$ & 17.61 & 18.29 & 19.11 \\
\hline
\end{tabular}

Table 6. Controlled non-uniform flow measurement results at the minimum air flow rate $\left(3750 \mathrm{~m}^{3} / \mathrm{h}\right)$

\begin{tabular}{|c|c|c|c|}
\hline Meas. ID & HE2-10a & HE2-11a & HE2-12a \\
\hline $\mathrm{V}_{\mathrm{w}}, \mathrm{dm}^{3} / \mathrm{min}$ & 16.7 & 22.3 & 26.5 \\
\hline $\mathrm{t}_{\mathrm{w}, \text { in }}{ }^{\circ} \mathrm{C}$ & 49.9 & 49.8 & 50.1 \\
\hline $\mathrm{t}_{\mathrm{w}, \text { out }}{ }^{\circ} \mathrm{C}$ & 45.8 & 46.4 & 46.9 \\
\hline $\mathbf{Q , k W}$ & 4.58 & 5.09 & 5.63 \\
\hline Meas. ID & HE2-13a & HE2-14a & HE2-15a \\
\hline $\mathrm{V}_{\mathrm{w}}, \mathrm{dm}^{3} / \mathrm{min}$ & 16.7 & 22.3 & 26.5 \\
\hline $\mathrm{t}_{\mathrm{w}, \mathrm{in}}{ }^{\circ} \mathrm{C}$ & 70.4 & 70.5 & 69.9 \\
\hline $\mathrm{t}_{\mathrm{w}, \text { out }}{ }^{\circ} \mathrm{C}$ & 61.1 & 64.7 & 66.2 \\
\hline $\mathbf{Q}, \mathbf{k W}$ & 10.45 & 8.68 & 6.59 \\
\hline Meas. ID & HE2-16a & HE2-17a & HE2-18a \\
\hline $\mathrm{V}_{\mathrm{w}}, \mathrm{dm}^{3} / \mathrm{min}$ & 16.2 & 21.9 & 26.3 \\
\hline $\mathrm{t}_{\mathrm{w} \text {,in }}{ }^{\circ} \mathrm{C}$ & 89.3 & 89.4 & 89.8 \\
\hline$t_{\mathrm{w}, \text { out }}{ }^{\circ} \mathrm{C}$ & 75.8 & 80.6 & 81.5 \\
\hline $\mathbf{Q}, \mathbf{k W}$ & 14.78 & 12.95 & 14.67 \\
\hline
\end{tabular}

\subsection{Comparative analysis}

A comparative analysis was carried out to fully assess the validity of the application of the tested technique to improve the heat output of the heat exchanger under consideration. The analysis results are listed in the two tables below.

Table 7 compares the results obtained experimentally. These results are very optimistic, as they indicate the possibility of achieving an efficiency increase of up to $20 \%$. However, when assessing these results, measurement uncertainties should be taken into account. The maximum measurement uncertainty (determined by the uncertainty propagation method) is $2.5 \%$, which proves that considering the efficiency improvement option examined herein is justified.

Table 8 compares the experimental and computational results. The second column of the table presents the results of the comparison between numerically obtained results and those measured for the uncontrolled non-uniform flow. The presented values show a significant influence of the uneven supply of mediums on the heat exchanger operation. For the case under consideration, the decrease in the heat output is up to $20 \%$. 
Table 7. Comparison of experimental results

\begin{tabular}{|c|c|c|c|}
\hline Case & QuNU, kW* & $\mathbf{Q}_{\mathrm{CNU}}, \mathbf{k} \mathbf{W}^{* *}$ & $\delta_{\mathrm{Q}}, \%$ \\
\hline HE2-01 & 4.95 & 5.61 & 13.3 \\
\hline HE2-02 & 6.22 & 6.98 & 12.2 \\
\hline HE2-03 & 5.92 & 6.78 & 14.5 \\
\hline HE2-04 & 9.55 & 10.85 & 13.6 \\
\hline HE2-05 & 10.99 & 12.65 & 15.1 \\
\hline HE2-06 & 12.07 & 14.04 & 16.3 \\
\hline HE2-07 & 14.61 & 17.61 & 20.5 \\
\hline HE2-08 & 15.42 & 18.29 & 18.6 \\
\hline HE2-09 & 15.78 & 19.11 & 21.1 \\
\hline HE2-10 & 4.31 & 4.58 & 6.3 \\
\hline HE2-11 & 4.82 & 5.09 & 5.6 \\
\hline HE2-12 & 5.36 & 5.63 & 5.0 \\
\hline HE2-13 & 9.79 & 10.45 & 6.7 \\
\hline HE2-14 & 8.25 & 8.68 & 5.2 \\
\hline HE2-15 & 6.29 & 6.59 & 4.8 \\
\hline HE2-16 & 13.57 & 14.78 & 8.9 \\
\hline HE2-17 & 12.02 & 12.95 & 7.7 \\
\hline HE2-18 & 13.53 & 14.67 & 8.4 \\
\hline
\end{tabular}

* - UNU - uncontrolled non-uniform flow case

** - CNU - controlled non-uniform flow case

Table 8. Comparison of experimental and numerical results

\begin{tabular}{|c|c|c|}
\hline Case & $\delta_{\mathrm{Q}}: \mathrm{U}-\mathrm{UNU}, \%$ & $\delta_{\mathrm{Q}}: \mathrm{U}-\mathrm{CNU}, \%$ \\
\hline HE2-01 & -10.6 & 1.3 \\
\hline HE2-02 & -12.4 & -1.7 \\
\hline HE2-03 & -14.5 & -2 \\
\hline HE2-04 & -11.5 & 0.6 \\
\hline HE2-05 & -14.3 & -1.3 \\
\hline HE2-06 & -16.1 & -2.4 \\
\hline HE2-07 & -13.1 & 4.8 \\
\hline HE2-08 & -15.9 & -0.3 \\
\hline HE2-09 & -18.7 & -1.5 \\
\hline HE2-10 & -4.6 & 1.3 \\
\hline HE2-11 & -5.9 & -0.6 \\
\hline HE2-12 & -8.8 & -4.3 \\
\hline HE2-13 & -5.3 & 1.1 \\
\hline HE2-14 & -7.1 & -2.3 \\
\hline HE2-15 & -9.6 & -5.3 \\
\hline HE2-16 & -5.6 & 2.8 \\
\hline HE2-17 & -7.9 & -0.8 \\
\hline HE2-18 & -10.1 & -2.5 \\
\hline
\end{tabular}

The comparison of the heat exchanger performance for the uniform flow (numerically obtained results) and the controlled non-uniform flow (experimental data) is shown in the third column of Table 8 . The use of inserts to direct a larger flow of air improves the situation, and the effect is in some cases even better than equalizing the air supply - up to almost $5 \%$.

\section{Conclusions}

The results obtained in this work confirm the hypothesis assuming the possibility of improving the heat exchanger performance by applying a non-uniform but controlled inflow of mediums.

The experimental results show that the heat exchanger output may be improved by even up to $20 \%$, compared to an uncontrolled non-uniform flow case. Numerically obtained results for the uniform inflow of mediums are usually better than for the controlled nonuniform flow. However, there were also cases for which the exchanger performance was improved by about $5 \%$ comparing to the uniform inflow of mediums case.

The outcomes of the presented analysis are in agreement with the previous investigations realized for similar heat exchangers and regarding the deterioration of the heat exchanger output due to the non-uniformity of the flow of mediums. The highest observed reduction in the total heat transfer rate is almost $19 \%$ compared to the uniform mediums flow case.

It is worth mentioning that the application of such a method of controlling the gas inflow seems to be easy and does not pose many technical problems.

The work was realized within the statutory scientific research of the Faculty of Energy and Environmental Engineering of the Silesian University of Technology.

\section{References}

1. R.S. Neve, Y.Y. Yan, Enhancement of heat exchanger performance using combined electrohydrodynamic and passive methods, International Journal of Heat and Fluid Flow, Volume 17, Issue 4, 1996, pp. 403-409, ISSN 0142-727X, https://doi.org/10.1016/0142727X(95)00016-J.

2. Chirag Maradiya, Jeetendra Vadher, Ramesh Agarwal, The heat transfer enhancement techniques and their Thermal Performance Factor, Beni-Suef University Journal of Basic and Applied Sciences, Volume 7, Issue 1, 2018, pp. 1-21, ISSN 2314-8535, https://doi.org/10.1016/j.bjbas.2017.10.001.

3. Moghaddaszadeh, N., Esfahani, J.A. \& Mahian, O. Performance enhancement of heat exchangers using eccentric tape inserts and nanofluids. $J$ Therm Anal Calorim 137, 865-877 (2019). https://doi.org/10.1007/s10973-019-08009-x

4. Chiou, J.P., Thermal performance deterioration in crossflow heat exchanger due to the flow nonuniformity, Journal of Heat Transfer, vol. 100, No. 4, pp. 580-587, 1978.

5. Ranganayakulu, Ch., Seetharamu, K.N., and Sreevatsan, K.V., The effects of inlet fluid flow nonuniformity on thermal performance and pressure drops in cross-flow plate-fin compact heat 
exchangers, International Journal of Heat and Mass Transfer, vol. 40, pp. 27-38, 1997.

6. Guo, J., Huai, X., Cheng, K., Cui, X., and Zhang, $H$., The effects of nonuniform inlet fluid conditions on crossflow heat exchanger, International Journal of Heat and Mass Transfer, vol. 120, pp. 807-817, 2018.

7. Piątek, R., Analiza termodynamiczna ożebrowanego wymiennika ciepła z nierównomiernym dopływem czynników [Thermodynamic analysis of the plate fin-and-tube heat exchanger with an unequal inflow of mediums], $\mathrm{PhD}$ dissertation, Institute of Thermal Technology, Silesian University of Technology, Gliwice, 2003.

8. T.Bury, J.Składzień, M.Hanuszkiewicz-Drapała, Experimental and numerical analyses of a nonuniform agents flow impact on a finned cross-flow heat exchanger effectiveness, Proceedings of the 22nd International Conference on Efficiency, Cost, Optimization, Simulation and Environmental Impact of Energy Systems - ECOS 2009, Foz do Iguacu, Parana, Brazil, on CD, 2009.

9. Bury, T., Składzień, J., and Widziewicz, K., Experimental and numerical analyses of finned cross flow heat exchangers efficiency under nonuniform gas inlet flow conditions, Archives of Thermodynamics, vol. 31, No. 4, pp. 133-144, 2010.

10. Bury, T., Hanuszkiewicz-Drapała, M., and Widziewicz, K., The finite difference method and the numerical approach for modeling the maldistribution of the flow of media in tube-andfin cross-flow heat exchangers, Heat Transfer Engineering, vol. 39, No. 13-14, pp. 1179-1191, 2018.

11. Hanuszkiewicz-Drapała M., Bury T., Widziewicz K.: Numerical model of a cross-flow heat exchanger with non-uniform flow of media. Journal of Power Technologies, 93 (5) (2013), pp. 295-302.

12. K.Widziewicz, Analiza termodynamiczna krzyżowoprądowego wymiennika ciepła z uwzględnieniem nierównomierności dopływu czynników i promieniowania cieplnego [Thermodynamic analysis of a cross-flow heat exchanger including a non-uniform inflow of mediums and the radiative heat transfer], $\mathrm{PhD}$ dissertation, Institute of Thermal Technology, Silesian University of Technology, Poland, 2014.

13. T.Bury, J.Składzień, Evaluation of selected methods of mitigation of media flow maldistribution impact in finned cross-flow heat exchangers. 3rd International Conference on Contemporary Problems of Thermal Engineering, 18-20 September 2012, Gliwice. 